\title{
Kosthold, kolesterol og karbohydrater
}

\author{
Er karbohydrater veldig usunt og hovedgrunnen til at man blir overvektig? Og er fett generelt, ja kanskje til og \\ med mettet fett, ikke så farlig likevel? Dette er et forsøk på å gi en oppsummering av hva vi vet \\ om dette per i dag, og hva jeg mener vi bør anbefale vår befolkning.
}

Tor Ole Klemsdal

tor.ole.klemsdal@vikenfiber.no

De siste par år har vi i Norge opplevd en intens kostholdsdebatt som har preget mange avisførstesider og også vært godt synlig i Tidsskriftet. Bøker om kosthold har blitt bestselgere, og publikum er blitt servert både revolusjonerende suksesshistorier og blitt vist advarende pekefinger når det gjelder karbohydratreduserte dietter. For mange mennesker, inkludert mange hjertepasienter, har denne debatten virket forvirrende og skapt usikkerhet om hvordan man skal forholde seg. Er ikke lenger den såkalte middelhavsdietten å anse som optimal for å forebygge hjerte- og karsykdom? For å kunne gi et utdypende svar på hva ulike kosthold betyr helsemessig, er det viktig å trekke inn kunnskap fra så vel epidemiologi, kliniske forsøk ved hjerte- og karsykdommer, samt studier av fysiologiske effekter som kroppsvekt og kolesterolnivå.

\section{Lærdom fra de \\ siste $\mathbf{4 0}$ års erfaringer}

I Norge og Nord-Europa har det vært bemerkelsesverdig stor nedgang i hjerteog karsykdom de siste 40 årene. Fra 1970 til 2011 har det i Norge vært en reduksjon i antall dødsfall som følge av hjerteinfarkt på $81 \%$, fra 4133 til 776 (tall for begge kjønn) i alderen 35-74 år (1). Selv om noe av denne positive endringen skyldes bedre medisinsk behandling, viser flere analyser fra nordiske land at størstedelen skyldes nedgang i befolkningens kolesterolnivå, avtakende røyketendens og lavere blodtrykk (2-4). I Norge var gjennomsnittsverdien for totalkolesterol nær $7 \mathrm{mmol} / \mathrm{l}$ for 40 år siden, men ligger nå rundt $5,5 \mathrm{mmol} / 1$ (5). Også blodtrykket synes å gå ned, særlig merkbart de siste 15 årene (6). Bakgrunnen for nedgangen i kolesterolnivå og synkende blodtrykk er nok sammensatt, men overgang fra et typisk nordeuropeisk kosthold til et kosthold mer likt det man har hatt rundt Middelhavet synes å være en hovedfaktor (7). Dette innebar bl.a. reduksjon i inntak av transfett, animalsk (mettet) fett og sterk saltholdig mat, og økt inntak av vegetabilske oljer, frukt og grønnsaker og mer fjærkre og fisk. Disse konsistente data om gunstige endringer i kosthold, risikofaktorer og dødelighet av hjerte- og karsykdommer står i kontrast til det medieskapte bildet av Ola og Kari Nordmanns levemåte, som oftest blir fremstilt som dramatisk forverret de siste 40 årene.

\section{Bra for hjertet, men dårlig mot overvekt?}

Den intense kostholdsdebatten i Norge kan altså neppe skyldes at gjeldende kostråd ikke har fungert for befolkningens hjerteog karrisiko, men at overvekt samtidig har blitt et akselererende helseproblem. Andelen med fedme, dvs. kroppsmasseindeks over 30, har i Norge økt fra 8-10\% i 1985 til et sted rundt $20 \%$ i dag, med tilhørende økning av diabetes 2 (6). I tillegg til at overvekt øker risikoen for mange fremtidige helseplager, vil mange her og nå oppleve fedme som negativt med hensyn til utseende, selvfølelse og deltakelse i sosiale sammenhenger. Et kosthold som gir rask og stor vektnedgang kan da virke mer attraktivt enn en diett som hjelper lite mot overvekt, selv om den skulle bety lavere hjerte- og karrisiko.

\section{Misforhold mellom \\ sunnhet og vektnedgang}

For at kostholdet skal være helsebringende må en rekke krav ivaretas. Vi trenger vitaminer, mineraler, essensielle aminosyrer, fettsyrer, antioksidanter, kostfiber osv., og vi må ha et visst energiinnhold for muskelarbeid og hvileforbrenning. Men mens kostens ernæringsmessige sammensetning har avgjørende betydning for helse og sykdom, har den skuffende liten betydning med hensyn til vekt. Et eksperiment fra en ernæringsprofessor Mark Haub ved Kansas State University illustrerer dette poenget. Med utgangspunktet i sin egen moderate overvekt, valgte Haub i en periode å spise kun kjeks og sjokoladekjeks, småkaker, sukrede kornblandinger og maischips (doritos), samt et glass proteinholdig ernæringsdrikk og en liten porsjon bønner eller andre grønnsaker (8). Men energiinnholdet var lavt, bare ca. 1800 kalorier daglig. Etter ti uker på denne dietten hadde Haub gått ned $11 \mathrm{~kg}$ i vekt, og konsentrasjonen av kolesterol og triglyserider var redusert med $20-30 \%$. På forhånd hadde ernæringsprofessoren et velansett kosthold med grove kornprodukter, fiber, frukt og bær, mens slankekuren var dominert av raske karbohydrater og ugunstig fett. Selv om et slikt enmannseksperiment har liten vitenskaplig verdi, gir det grunnlag for tre viktige erkjennelser:

- Man kan bli overvektig selv om matens sammensetning er bra.

- Man kan gå ned i vekt uten å ha et godt sammensatt kosthold.

- Når man får i seg så lite kalorier at vekten raser nedover, vil kolesterol- og triglyseridverdier iallfall midlertidig kunne utvikle seg gunstig, til tross for en sammensetning som normalt anses uheldig.

\section{Gir lavkarbodietter mer vekttap?}

Til tross for mange suksesshistorier om flott vektnedgang på et strengt karbohydratfattig kosthold, finner man i publisert litteratur ikke holdepunkter for at kostens sammensetning har særlig betydning, når man ser bort fra de første seks månedene etter kostintervensjon. I en serie omfattende kartlegginger av kosthold og vektutvikling i flere europeiske land påvirket verken andelen fett, andelen mettet fett, glykemisk indeks (load), proteininntak, inntak av frukt og grønt eller fiber vektutviklingen mer enn tilsvarende $50 \mathrm{~g}$ per år $(9,10)$. Den til nå største randomiserte, kontrollerte studien med oppfølging i to år viste heller ikke signifikant vektforskjell når inntaket av karbohydrater ble variert fra $35 \%$ til $65 \%$, andelen proteiner fra $15 \%$ til $25 \%$ og andelen fett fra $20 \%$ til $40 \%$ (11). I en egen studie på 202 pasienter med varierende grader av metabolsk syndrom så vi heller ingen signifikant forskjell i vektreduksjonen etter 12 måneder når pasienten ble randomisert til råd om enten å holde en lavglykemisk diett eller en tradisjonell lavfettdiett (12). En metaanalyse av 22 tilsvarende studier rapporterte også kun ca. 1 kg differanse, som ikke var signifikant (13). Det er 


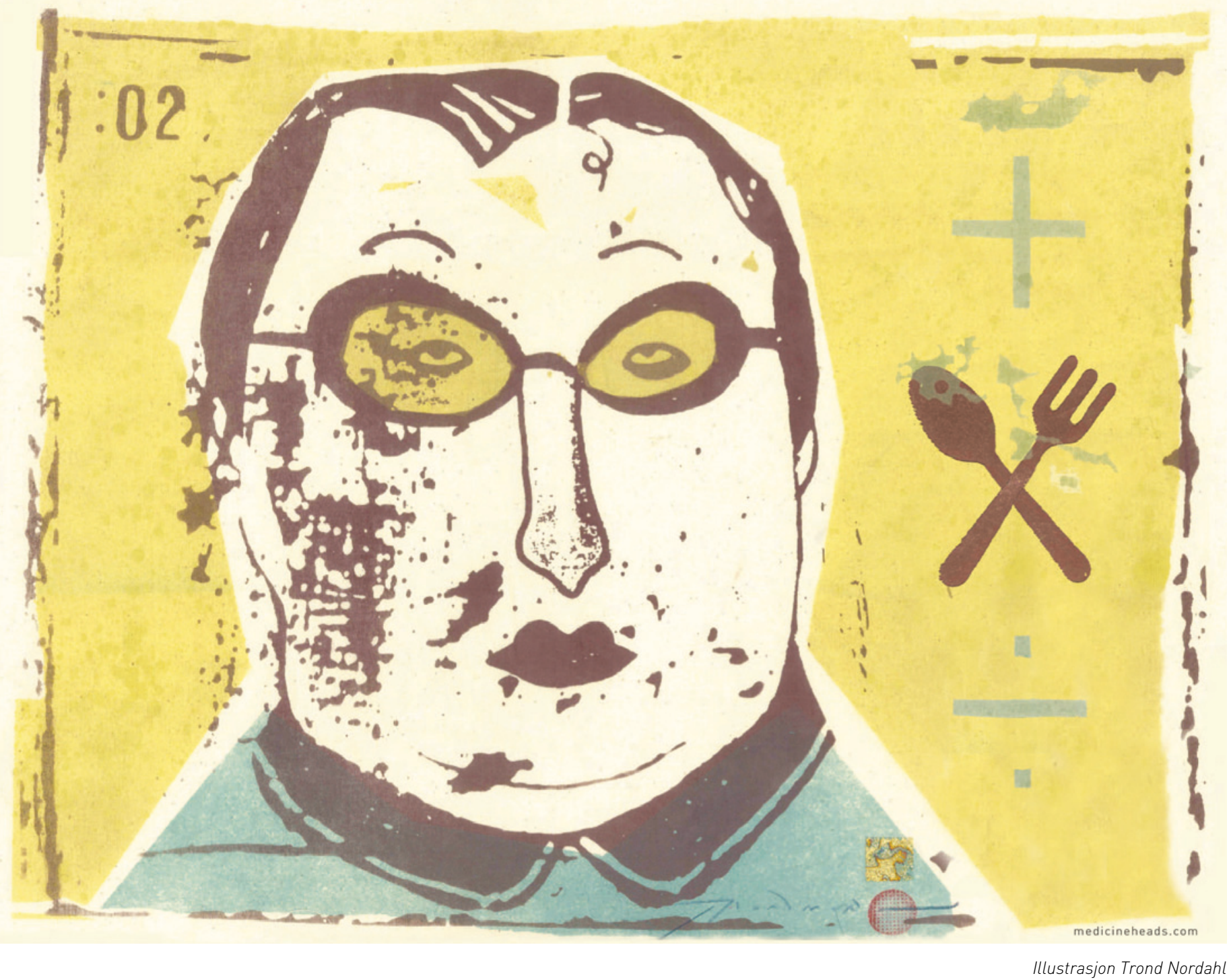

altså ikke dekning for å hevde at lavkarbodietter generelt gir nevneverdig mer vekttap enn lavfettdietter, når man følges i mer enn 6-12 måneder.

\section{Hva skjer så med kolesterolet?}

I vår studie ble LDL-kolesterolkonsentrasjonen liggende uendret på gjennomsnittlig $3,7 \mathrm{mmol} / 1$ etter 12 måneder med karbohydratredusert kost (12). I denne studien innebar imidlertid lavkarbohydratdietten ingen vesentlig økning i inntaket av mettet fett, som i gjennomsnitt ble liggende rundt $12 \%$ av energiinntaket. Den tidligere omtalte metaanalysen viste også små utslag på lipidverdiene, men noe lavere LDL-kole- sterolnivå ved lavfettdietter, men lavere verdier av triglyserider og høyere av HDLkolesterol ved karbohydratreduserte dietter (13). Langt større utslag er imidlertid rapportert når inntaket av mettet fett er økt mer markant. En konsentrasjonsøkning i LDLkolesterol på $0,6 \mathrm{mmol} / 1$, fra 3,2 til 3,8, ble observert hos 55 personer gitt en lavkarbodiett med $38 \mathrm{~g}$ mettet fett per dag, tilsvarende $20 \%$ av energiinntaket (14). En slik nivåøkning i LDL-kolesterol på $0,6 \mathrm{mmol} / 1$ er assosiert med en økning av risikoen for hjerteinfarkt i størrelsesorden 15-20\% (3). Resultatene harmonerer med Oslo-undersøkelsen fra 1981 (15), der inntaket av mettet fett ble redusert fra $18 \%$ til $8 \%$, og total- kolesterolkonsentrasjonen ble redusert med $14 \%$. Denne studien må regnes som banebrytende innen livsstilsintervensjon, og siteres fortsatt som en av ganske få randomiserte, kontrollerte livsstilsstudier som har vist signifikant effekt på forekomst av hjerteinfarkt.

\section{Har de offisielle kostholdsrådene vært gode nok?}

På helsenorge.no - den offentlige helseportalen (med henvisning til Helsedirektoratet) kan man lese følgende under overskriften «Jeg vil ned i vekt»: «Overvekt kommer nesten allitid av at man spiser mat med mer kalorier (energi) enn det man bruker. ... 
Dette betyr ikke at du må spise lite selv om du ønsker å gå ned i vekt. Dersom du spiser mye fisk, frukt, grønnsaker, poteter og brød, kan du fortsatt spise mye mat, fordi denne maten gir lite kalorier og fett» (16).

De norske offisielle anbefalingene legger også stor vekt på fysisk aktivitet, både for å forebygge overvekt og som tiltak for vektreduksjon, samt at mat med redusert energitetthet (det vil si få kalorier per vektenhet matvare) er gunstig.

Det er liten tvil om at de ovennevnte offisielle råd i all hovedsak er godt fundert og velegnet til å fremme god helse. Rådene kan likevel gi inntrykk av at godt sammensatt kosthold og fysisk aktivitet er mer effektivt mot overvekt enn det vi har vitenskapelig grunnlag for. Mindre gunstig er det at behovet for å redusere porsjoner og totalt matinntak synes bagatellisert. Gevinsten av å spise mindre fett, og da særlig mettet fett, synes derimot noe overvurdert. I nyere oversiktsartikler blir det fremhevet at helsegevinsten av fettreduksjon er begrenset eller fraværende, dersom karbohydrater erstatter fettet $(17,18)$, mens erstatning med umettet fett gir en viss gevinst. Transfett fremstår derimot stadig som særs ugunstig, og bør unngås (18). Ettersom lavkarbodietter med høyt fettinnhold har vist seg like effektive som tradisjonelle lavfettdietter med tanke på å redusere overvekt, synes det også tvilsomt om matens energitetthet har nevneverdig betydning for vektutviklingen, da høyt fettinnhold (i tillegg til høyt sukkerinnhold) medfører høy energitetthet. Heller ikke epidemiologisk rapporteres kostens energitetthet å ha noen stor betydning (19).

Den vektreduserende effekten av fysisk aktivitet alene eller på toppen av kostendringer, er dessverre også mer begrenset enn hva de offisielle anbefalinger kan gi inntrykk av - med en reduksjon anslått til ca. $1 \mathrm{~kg}$ ved aktivitet tilsvarende 30 minutters rask gange seks ganger per uke i 6-12 måneder (20).

\section{Oppsummering}

Gunstige endringer i kosthold og røykevaner har gitt viktige bidrag til redusert forekomst av hjerte- og karsykdom i Norge de siste 40 årene, men de samme kostendringene har ikke kunnet hindre en betydelig vektøkning i befolkningen. Fortsatt søkelys på kost med lite fett, lav energitetthet $\mathrm{og}$ rikelig med frukt og grønt vil neppe vise seg mer effektivt $i$ årene som kommer, og noen større vektreduksjon ved økt fysisk aktivitet synes heller ikke realistisk. Over- gang til karbohydratredusert kosthold gir imidlertid heller ikke nevneverdig bedre vektutvikling, og en ugunstig økning av LDL-kolesterolkonsentrasjonen må påregnes ved uttalt høyfettdietter med en andel mettet fett over 18-20\%. For hjertepasienter er det viktig å være klar over at helsegevinsten ved å ivareta et hjertevennlig kosthold etter mønster fra middelhavsdietten er langt større enn den man kan forvente av noen kilo vektnedgang. Mer moderat karbohydratreduserte dietter synes imidlertid likeverdige med tradisjonelle kostråd, og kan utvilsomt fungere utmerket for mange mennesker, kanskje særlig når det foreligger metabolsk syndrom (12).

Selv om det kan synes skuffende at man ikke har kunnet identifisere kostelementer som har avgjørende betydning for vektutviklingen, betyr dette også stor frihet i valg av velsmakende matvarer. Den tryggeste måten å ivareta et helsefremmende kosthold på er ut fra dagens viten stadig gjennom den såkalte middelhavsdietten (18), mens forsiktighet med matmengde og porsjoner gjenstår som det eneste virkelig effektive for vektkontroll. Jo klarere dette budskapet når ut til helsepersonell, personer med overvekt og til den generelle befolkning, jo mindre forvirring og bortkastede tiltak vil vi få og jo større er muligheten for å lykkes med å møte en av vår tids største helseutfordringer.

\section{Tor Ole Klemsdal (f. 1958)}

er spesialist i indremedisin og kardiologi og seksjonsleder ved preventiv kardiologi, Avdeling for endokrinologi, sykelig overvekt og forebyggende medisin, Medisinsk klinikk, Oslo universitetssykehus, Ullevål.

Forfatter har fylt ut ICMJE-skjemaet og oppgir ingen interessekonflikter.

\section{Litteratur}

1. Statistisk sentralbyrå. Statistikkbanken www.statbank.ssb.no/statistikkbanken/selectout/ print.asp?Fileformatld $=2 \&$ Queryfile $=$ 201211317273522416319DodsfallHjerteKar\& PLanguage $=0 \&$ MainTable=DodsfallHjerteKar\& potsize $=8$. (2.11.2012)

2. spelund T, Gudnason V, Magnusdottir BT et al. Analysing the large decline in coronary heart disease mortality in the Icelandic population aged 25-74 between the years 1981 and 2006. PLoS ONE 2010; 5: e13957.

3. Björck L, Rosengren A, Bennett K et al. Modelling the decreasing coronary heart disease mortality in Sweden between 1986 and 2002. Eur Heart J 2009; 30: 1046-56
4. Laatikainen T, Critchley J, Vartiainen E et al. Explaining the decline in coronary heart disease mortality in Finland between 1982 and 1997. Am J Epidemiol 2005; 162: 764-73.

5. Norheim OF, Gjelsvik B, Kjeldsen SE et al. Retningslinjer for individuell primærforebygging av hjerte- og karsykdommer. Oslo: Helsedirektoratet 2009

6. Folkehelse i endring. Helseundersøkelsen NordTrøndelag HUNT 1 (1984-86) - HUNT 2 (1995-97) - HUNT 3 (2006-08) www.ntnu.no/hunt/. Levanger: HUNT forskningssenter, 2011

7. Pedersen JI, Tverdal A, Kirkhus B. Kostendringer og dødelighetsutvikling av hjerte- og karsykdommer i Norge. Tidsskr Nor Lægeforen 2004; 124: $1532-6$.

8. Twinkie diet helps nutrition professor lose 27 pounds. www.edition.cnn.com/2010/HEALTH/11/ 08/twinkie.diet. professor/index.html (2.11.2012)

9. Du H, Feskens E. Dietary determinants of obesity. Acta Cardiol 2010; 65: 377-86

10. Vergnaud AC, Norat T, Romaguera D et al. Fruit and vegetable consumption and prospective weight change in participants of the European Prospective Investigation into Cancer and Nutrition-Physical Activity, Nutrition, Alcohol, Cessation of Smoking, Eating Out of Home, and Obesity study. Am J Clin Nutr 2012; 95: 184-93.

11. Sacks FM, Bray GA, Carey VJ et al. Comparison of weight-loss diets with different compositions of fat, protein, and carbohydrates. N Engl J Med 2009: 360: 859-73.

12. Klemsdal TO, Holme I, Nerland $\mathrm{H}$ et al. Effects of a low glycemic load diet versus a low-fat diet in subjects with and without the metabolic syndrome. Nutr Metab Cardiovasc Dis 2010; 20: 195-201.

13. Hu T, Mills KT, Yao L et al. Effects of low-carbohydrate diets versus low-fat diets on metabolic risk factors: a meta-analysis of randomized controlled clinical trials. Am J Epidemiol 2012; 176 (suppl 7). S44-54.

14. Brinkworth GD, Noakes M, Buckley JD et al. Longterm effects of a very-low-carbohydrate weight loss diet compared with an isocaloric low-fat diet after 12 mo. Am J Clin Nutr 2009; 90: 23-32.

15. Hjermann I, Velve Byre K, Holme I et al. Effect of diet and smoking intervention on the incidence of coronary heart disease. Report from the Oslo Study Group of a randomised trial in healthy men. Lancet 1981; 2: 1303-10.

16. helsenorge.no den offentlige helseportalen. www.helsenorge.no/ Helseogsunnhet/Sider/ Jeg-vil-ned-i-vekt.aspx (6.12.2012)

17. Micha R, Mozaffarian D. Saturated fat and cardiometabolic risk factors, coronary heart disease, stroke, and diabetes: a fresh look at the evidence. Lipids 2010; 45: 893-905

18. Mente A, de Koning L, Shannon HS et al. A systematic review of the evidence supporting a causal link between dietary factors and coronary heart disease. Arch Intern Med 2009; 169: 659-69.

19. Du H, van der A DL, Ginder V et al. Dietary energy density in relation to subsequent changes of weight and waist circumference in European men and women. PLoS ONE 2009; 4: e5339.

20. Wadden TA, Webb VL, Moran CH et al. Lifestyle modification for obesity: new developments in diet. physical activity, and behavior therapy. Circulation 2012; 125: 1157-70

Mottatt 7.6. 2012, første revisjon innsendt 18.11 2012, godkjent 3.12. 2012. Medisinsk redaktør Kristin Viste.

Podkast på www.tidsskriftet.no 